J. Clin. Chem. Clin. Biochem.

Vol. 17, 1979, pp. 537-539

\title{
Platelet Counting with a Laser Nephelometer
}

\author{
By D. J. Giannitsis
}

Abt. f. Klin. Haemostaseologie und Transfusionsmedizin in den Universitätskliniken, Homburg/Saar

(Received April 19/October 25, 1978)

Summary: A method for platelet counting is described, based on the Laser nephelometric principle. Experimental results are reported, together with the practical considerations for the standardisation and correlation of the method, and for application of the method in the routine biochemical laboratory.

Venous blood, taken with EDTA-NaCl solution according to Schulz et al $(1971, \mathrm{Z}$. Klin. Chem. Klin. Biochem. 9 , $329-333$ ) is used. The blood is centrifuged at $100 \mathrm{~g}$ for $10 \mathrm{~min}$ and $10 \mu \mathrm{l}$ of the supernatant is added to $3000 \mu \mathrm{l}$ of a suspending medium (dilution 1:80); $300 \mu \mathrm{l}$ platelet suspension are read in a nephelometer cuvet or tube against blank. The number of platelets per liter blood are determined with the aid of a standard curve. The sensitivity and reproducibility of the method, and the correlation with the "electronic coulter counting" method are satisfactory.

\section{Thrombocyten-Zählung mit einem Laser-Nephelometer}

Zusammenfassung: Es wird eine Methode zur Bestimmung der Blutplättchenzahl beschrieben. Die Methode basiert auf dem Laser-nephelometrischen Prinzip. Experimentelle Ergebnisse werden mitgeteilt, wobei neben der Standardisierung der Methode vor allem praktische Gesichtspunkte, z.B. Korrelation mit anderen Methoden usw., berücksichtigt werden. Die Standard-Methode wird wie folgt angegeben: Venenblut wird mit EDTA-NaCl-Lösung nach der Methode von Schulz et al (1971), Z. Klin. Chem. Klin. Biochem. 9, 329-333) aufgezogen. Anschließend wird das Blut bei $100 \mathrm{~g} 10 \mathrm{~min}$ zentrifugiert, $10 \mu \mathrm{l}$ des Plasma-Überstandes in $3000 \mu$ l Suspensionslösung pipettiert (Verdünnung 1:80), und davon werden $300 \mu l$ in eine spezielle Küvette oder Röhrchen gebracht. Die nephelometrische Messung erfolgt gegen die Blindprobe (plättchenfreies Plasma), und die relative Lichtstreuung in $\mathrm{mV}$ entspricht der Thrombocytenzahl, die dann in einer Standardkurve abgelesen werden kann.

Die Empfindlichkeit und die Reproduzierbarkeit der Methode wie auch die Korrelation zu den Methoden des "Electronic Coulter counter" sind befriedigend.

\section{Introduction}

A number of methods of platelet counting in biomedical research as well as in routine laboratories are reported in the literature $(1-3)$. The method of platelet counting with the Coulter (3) principle has now been in use for some time, and recently Schulz et al (1) have demonstrated a nephelometric method for platelet counting. The advantages of the nephelometric procedure have also been discussed recently (1).

Here we report a method for platelet counting by means of Laser nephelometry, together with the optimal con- . dition for its operation. The results are correlated with those of other methods of platelet counting. The findings and the possibility for application of our method in biochemical laboratories are briefly discussed.

\section{Material and Methods}

Venous blood, taken with EDTA-NaCl solution according to the method described by Schulz et al (1) is used as follows for platelet counting: $1.6 \mathrm{ml}$ venous blood with $0.4 \mathrm{ml}$ EDTA (Titriplex III, Merck 0.075 g/l)-dextran (Dextran 150, Pharmacia, Uppsala $0.125 \mathrm{~g} / \mathrm{l})-\mathrm{NaCl}(0.075 \mathrm{~g} / \mathrm{l})$-solution is drawn into a special $2 \mathrm{ml}$ syringe. The contents of the syringe are mixed, and transfered into a centrifuge tube. The blood is then centrifuged at $100 \mathrm{~g}$ for $10 \mathrm{~min}$ and $10 \mu \mathrm{l}$ of the supernatant (platelet rich plasma) is added to $3000 \mu \mathrm{l}$ of a suspending medium. $300 \mu \mathrm{l}$ of the platelet suspension are placed in a $1000 \mu$ nephelometric cuvet and read against a blank (=plasma without platelets). The number of platelets per liter blood are read from a present standard curve.

\section{The suspending medium}

Alternative suspending media are $8.5 \mathrm{~g} / 1 \mathrm{NaCl}$ solution, $220 \mathrm{~g} / \mathrm{l}$ albumin solution (Firma Merz \& Dade), or a mixture of FicollHypaque or Ficoll-Urografin solution, specific gravity 1.070, 
preformed as described elsewhere (4). The standard curve is derived from a dilution series of platelet stock suspension, obtained from healthy donor, calculated by the electronic Coulter counting method. The nephelometric readings in $\mathrm{mV}$ were compared to the known number of platelets.

Laser nephelometric counting is performed using a "Behring"Nephelometer. Statistical analysis is performed on the basis of the correlation between Laser nephelometry and electronic Coulter counting.

\section{Results}

The sedimentation of platelets over long periods of time under gravity depends both on density and viscosity of the suspending medium. Figure 1 shows the time-dependent stability of platelets after standing in various media. It becomes obvious that the platelets remain stable in suspended form in a medium of Ficoll-Urografin or FicollHypaque specific gravity 1.070 , or albumin solution $(220 \mathrm{~g} / \mathrm{l})$, as well as in autologous plasma. Laser nephelometric reading and electronic Coulter-counting of platelets are depicted in figure 2 . The correlation between

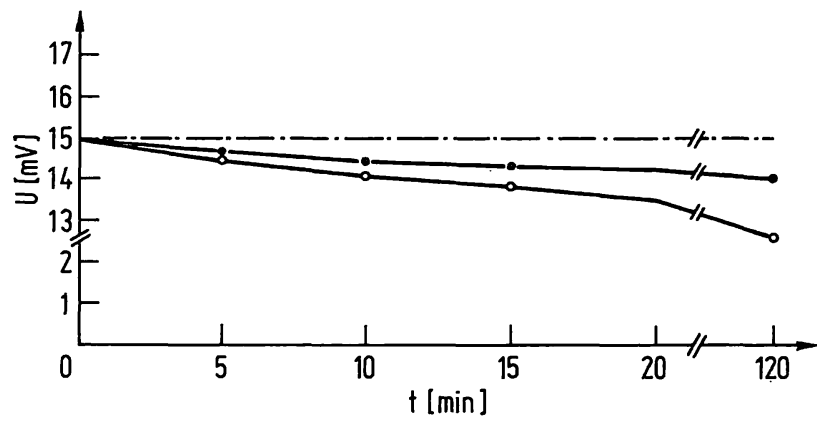

Fig. 1. Curve of time dependent stability (in $\mathrm{mV}$ ) after standing platelets (samples: $n=10$ ) in various media (normal saline $0 \longrightarrow$, autologous plasma $\longrightarrow$ and Ficoll-Urografin -..-. solution).

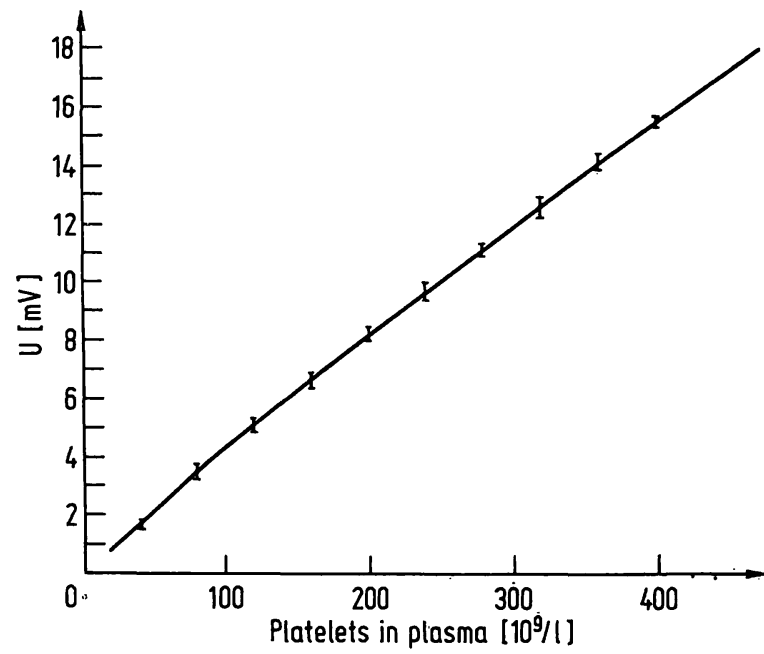

Fig. 2. Correlation between "electronic coulter" counting of platelets and Laser nephelometric principle. The number of platelets after an "electronic coulter" counting (horizontal coordinate) was correlated to the Laser nephelometric light scattering in $\mathrm{mV}$ (vertical coordinate; $\overline{\mathrm{x}} \pm \mathrm{s})$.
Laser nephelometry and electronic Coulter counting is shown in table 1 . The sensitivity of the method, depending on the concentration of the suspended particles, was studied against a standard amount of platelets in various concentrations. The dilution is performed with normal saline.

Táb. I. The relationship between electronic Coulter counting and the Laser nephelometric method for platelet counting, (Electronic Coulter counting $=X$, Laser nephelometric . $=Y, n=56$; The correlation coeff. $(r)=0.89$ ).

\begin{tabular}{|c|c|c|c|}
\hline Blood-sample Nr. & $\begin{array}{l}\text { Electronic Coulter } \\
{\left[10^{9} / 1\right]}\end{array}$ & \multicolumn{2}{|c|}{$\begin{array}{l}\text { Laser Nephelometer } \\
{\left[10^{9} / 1\right]}\end{array}$} \\
\hline 1 & 193 & 250 & \\
\hline 2 & 285 & 300 & \\
\hline 3 & 218 & 180 & \\
\hline 4 & 85 & 75 & \\
\hline 5 & 77 & 70 & . \\
\hline 6 & 133 & 185 & \\
\hline 7 & 157 & 160 & \\
\hline 8 & 331 & 350 & \\
\hline 9 & 170 & 200 & \\
\hline 10 & 178 & 180 & \\
\hline 11 & 45 & 60 & \\
\hline 12 & 210 & 265 & \\
\hline 13 & 174 & 183 & \\
\hline 14 & 412 & 460 & \\
\hline 15 & 121 & 130 & \\
\hline 16 & 157 & 98 & \\
\hline 17 & 189 & 190 & \\
\hline 18 & 153 & 145 & \\
\hline 19 & 21 & 20 & \\
\hline 20 & 102 & 85 & \\
\hline 21 & 14 & 12 & \\
\hline 22 & 267 & 210 & \\
\hline 23 & 260 & 250 & \\
\hline 24 & 128 & 150 & \\
\hline 25 & 64 & 62 & \\
\hline 26 & 1.08 & 98 & . \\
\hline 27 & 213 & 245 & . \\
\hline 28 & 369 & 380 & \\
\hline 29 & 256 & 240 & \\
\hline 30 & 402 & 450 & \\
\hline 31 & 290 & 295 & \\
\hline 32 & 320 & 360 & \\
\hline 33 & 12 & 11 & . \\
\hline 34 & 234 & 180 & \\
\hline 35 & 118 & 100 & \\
\hline 36 & 290 & 320 & \\
\hline 37 & 249 & 235 & \\
\hline 38 & 87 & 85 & \\
\hline 39 & 310 & 305 & \\
\hline 40 & 231 & 271 & \\
\hline 41 & 294 & 250 & \\
\hline 42 & 252 & 250 & \\
\hline 43 & 220 & 221 & \\
\hline 44 & 298 & 300 & \\
\hline 45 & 121 & 115 & \\
\hline 46 & 187 & 201 & \\
\hline 47 & 236 & 250 & \\
\hline 48 & 48 & 55 & \\
\hline 49 & 299 & 280 & \\
\hline 50 & 277 & 260 & \\
\hline 51 & 345 & 350 & \\
\hline 52 & 192 & 164 & \\
\hline 53 & 265 & 283 & . \\
\hline 54 & 379 & 400 & \\
\hline 55 & 327 & 120 & \\
\hline 56 & 65 & 65 & \\
\hline
\end{tabular}


Tab. 2. The reproducibility of platelet counting $(n=10)$ by Laser nephelometry, and the standard deviations.

\begin{tabular}{ll}
\hline Platelets count $\bar{x}\left[10^{6} / 1\right]$ & $\pm s\left[10^{6} / 1\right]$ \\
\hline 0.40 & 0.00022 \\
0.80 & 0.00046 \\
1.20 & 0.00060 \\
1.60 & 0.00081 \\
2.00 & 0.00099 \\
2.40 & 0.00128 \\
2.80 & 0.00128 \\
3.20 & 0.00137 \\
3.60 & 0.00150 \\
4.00 & 0.00268 \\
\hline
\end{tabular}

The reproducibility was checked for the same samples $(\mathrm{N}=10)$ and the standard deviation is also shown in table 2. The statistical relationship and correlation between both methods, Laser nephelometry and electronic Coulter counting, is represented in table 1.

\section{Discussion}

The advantages of the use of the nephelometric counting of platelets in comparison to other methods is discussed elsewhere (Schulz et al., (1)). Laser nephelometric measurement follows the law of Stockes (1) as well as the equation: $I=\frac{C}{K}(I=$ scattered light; $C=$ concentration of platelets, $\mathrm{K}=$ instrumental and working conditions (5)).

A problem of blood cell counting by nephelometric means lies in the rate of sedimentation of the particles.

Other problems are reproducibility of measurement, precision of the method and correlation with other methods. From figure 1 can be seen that the sedimentation rate of platelets in the first 20 minutes is very small, and the difference in count is less than $8 \%$ when using autologous serum, compared to other media like FicollHypaque, etc.

This is verified by the standard deviation (tab. 2) when counting the same platelet preparations. Precision of the method depends on the number of particles, as shown in table 1 and figure 2 . The correlation coefficient between Laser nephelometry and electronic Coulter counting is also presented in table 1 and figure 2.

The method of Laser nephelometry should be well suited for application in clinical laboratories, and may be combined with measurements of other cells or substances; also the method could be mechanized.

\section{Acknowledgement}

I thank Mr. R. Fuchs for technical assistance.

\section{References}

1. Schulz, V., Köstering, K., Walter, Ch. \& Kochsiek, K. (1971) Z. Klin. Chem. Klin. Bioch. 9, 329-333.

2. Caen, J. P., Cronberg, St. \& Kubisz, P. (1977) Platelets, Stratton Intercontinental Medical Book Corp. New York.

3. Coulter Symp., Bad Nenndorf, October 1968.
4. Giannitsis, D., Jarovici, A., Bessemans, J. \& Müller, M. (1978) Symp. "Coulter in der Medizin", Stuttgart-Münchingen, Mai 1976 (im Druck).

5. Curtius, H. \& Roth, M. (1974) Clin. Biochem. Vol. 1, pp 243, De Gruyter, Berlin, New York.
Dr. D. J. Giannitsis Universitätskliniken D-6650 Homburg/Saar 


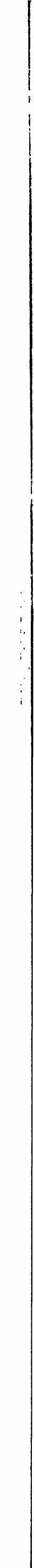


The MAT44S sthe solution

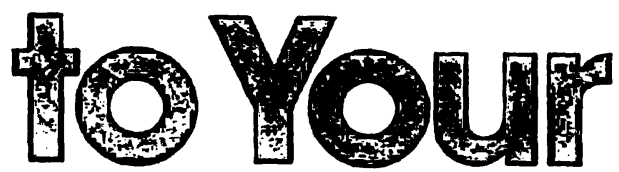

Areorying

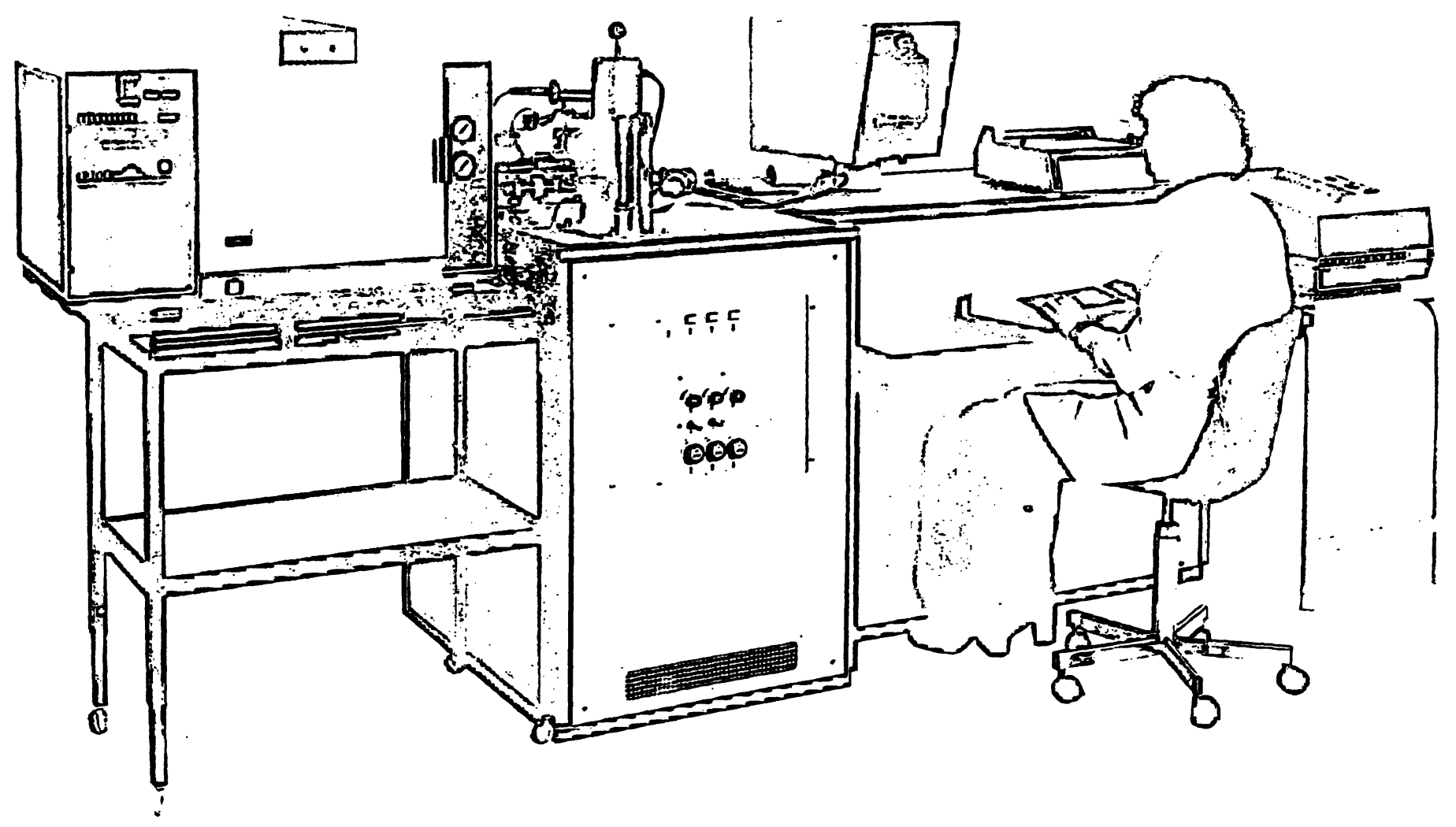

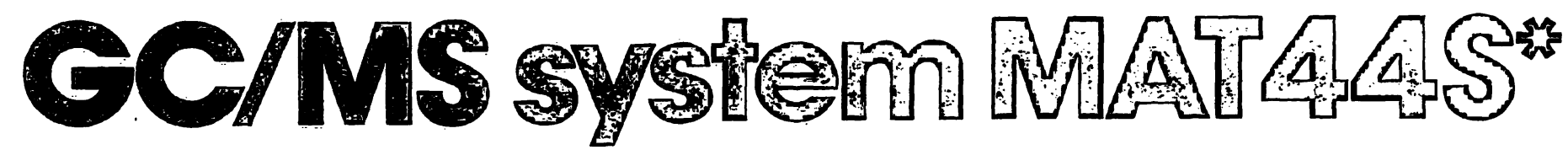

*Our GC/MS/DS package prices will also ease your funding problems.
Varian MAT GmbH, Postfach 144062 Barkhausenst.2,2800 Bremen 14 F.R.Germany, Telefon(O421)

VarianMATMass Spectrometry, 25 Hanover Rd., Florham Park, NJO7932, Phone (2O1) 822-3700,U.S. 
Gideon Blauer Horst Sund (Editors)

\section{Transport by Proteins}

\section{Proceedings of a Symposium held at the University of Konstanz, West Germany, July 9-15, 1978 FEBS Symposium No. 58}

Edited by Gideon Blauer, Ph. D., Professor of Biophysical Chemistry, Institute of Life Sciences, The Hebrew University, Jerusalem/lsrael and Horst Sund, Dr. rer. nat., Professor of Biochemistry, Biology Department, University of Konstanz/West Germany.

$1978.17 \mathrm{~cm} \times 24 \mathrm{~cm}$. XV, 420 pages. With numerous figures and tables. Hardcover DM 145,ISBN 3110076942

This book presents the proceedings (lectures and discussions) of a Symposium on "Transport by Proteins", held at the University of Konstanz. Well-known scientists discuss general problems, selected transport proteins, membranes and transport by proteins, metal transport by' proteins and the molecular aspects of transport by proteins in physiology and pharmacology.

The topic covers a wide range of different systems of fundamental physiological significance, such as the transport of oxygen, metabolites, metal ions, drugs, hormones etc., all mediated by proteins either in aequeous solution or through membraneous structures, including multi-enzyme complexes and the oxidation-reduction chains of respiration and photosynthesis. 